УДК 821.163.41.09

https://doi.org/10.18485/msc50.2019.1.ch50

\author{
Милорад Павић
}

\title{
ТЕМА ВЕЧИТОГ МЛАДОЖЕЊЕ У СРПСКОЈ КЊИЖЕВНОСТИ
}

\section{Увод}

Литература о Игњатовићевим романима, посебно о његовом, према уврењу многих оцењивача, најбољем делу - Вечитом младожени, прошла је од скерлићевих времена наовамо кроз различите фазе. Најпре схватан као друштвени роман, Вечити младожена подвргаван је потом другачијим проверама; наглашен је психолошки аспект дела (Дворниковић), упоредна истраживања која је чинио Савковић као да су прерано одбачена, а стилским особеностима Игњатовићевих романа забавили су се Герхард Геземан и Драгиша Живковић. Геземан је упутио истраживања и једним новим правцем. Упоредио је Игњатовићевог Шамику Кирића са „вечитим младожењом” у једном роману Готфрида Келера и са Андрићевим Алијом Ђерђелезом. Ово друго није било прихваћено и тако се у најновијим прегледима литературе, заузима становиште да таквог особеног типа као што је Шамика Кирић нема „више ни у Игњатовићевим делима, ни у српској књижевности уопште".

Нама се Геземанов прилаз чини занимљивим већ стога, што се показало да је тип „вечитог младожење” распрострањенији но што се на први поглед може закључити. Шамикин живот могао би се схватити као психолошка биографија многих типова које знамо из живота или из историје, таквих, као што су на пример, Милован Видаковић или чак Јован Пачић. Али, много је важније да тип вечитог младожење није редак ни у српској литератури, од рокајних времена до XX столећа. То и није чудно, јер напудрани удварач и галантни љубавник-играч доиста припада рококо салонима XVIII века. Укратко, ево дела у којима смо открили тип „вечитог младожење” или томе одговарајућу тематику:

1. Мемоари Симеона Пишчевића (око 1784),

2. Описаније живота Саве Текелије (пре 1833),

3. Вечити младожеюа Јакова Игњатовића (1878), 
4. Швабица и три повести о Јанку Лазе Лазаревића (после 1878),

5. Дневник о Чарнојевићу Милоша Црњанског (1920).

Овде треба напоменути да се за тему Швабице и њене главне мушке ликове - једног лекара и једног правника, везују и неке друге приповести Лазаревићеве, у којима ови јунаци добијају и устаљена имена - Јанка и Јоце. То су приповетке Вертер, Ветар и недовршена проза Побратими.

Да одмах кажемо, сва набројана дела и писци некако су у вези. Пишчевић је служио код генерала Петра Текелије, којег је синовац Сава Текелија посетио у Русији 1787. Описаније живота Саве Текелије објављено је у Летопису 1877. и 1879, дакле у часу када је бивши уредник тог истог Летописа, Игњатовић написао Вечитог младожену У том роману Игњатовић је скицирао „тему Швабице” коју ће прихватити Лазаревић исте године:

„- Шта вам се не допада?

- Та знаш сам, Швабица је!

- Па ви не бисте хтели Швабицу?

- Не зато што је Швабица по језику, већ што није нашег закона...”

Овај дијалог није из Лазаревићеве приповетке, него је разговор између Шамике и оца у Вечитом младожени. Најзад, Црњански као да скупља све нити у једну. Њему је добро познат Пишчевић, а његов Дневник о Чарнојевићу одиграва се једним делом у Сентандреји и ту се помиње Јаков Игњатовић.

Па ипак, ми не мислимо да ова дела треба упоређивати. Ми не желимо да истражујемо њихове узајмне везе и евентуална угледања једних писаца на друге. Овде бисмо хтели да из свих дела извучемо што јаснију дефиницију „вечитог младожење” надајући се да ће нам та, у суштини загонетна личност, тиме постати разумљива.

\section{1. Лик „вечитог младожење”}

Сви ти млади, лепи и добро у друштву примљени људи, од јунака Пишчћевићевих или Текелијиних мемоара до Шамике, Лазаревићевих ликова и Рајића у делу Црњанског, имају типичне галантне наклоности.

Пишчевић, на пример, осећао се као риба у води где год је било жена, музике и игре. Он је носио раскошне хусарске униформе, жуте кавалеријске чизме, бело перо на капи, лудовао је за лепим коњима и расним псима, за сребрним посуђем и свирањем у флауту. Обожавао је балове, пријеме, маскараде где су га понекад преодевали у женско, и увек пости- 
зао успехе у салонима и гостионицама где има жена и музике. На дугим војничким путевима у Елзасу, Пфалцу, Баварској, Штајерској, Славонији и Трансилванији, на дворским добрима пољске шљахте и мађарских спахија, по дворовима у Карловцима, по ватрометима, баловима и операма у Бечу, Пешти и Петрограду, жене су га опседале, дивиле се његовој појави, јахању, дугој црној коси посреди раздељеној, белом лицу, музикалности, спречености у игри и његовој лакој конверзацији. Био је од малих ногу учен сликању, игри и музици.

Текелија, који је после Пишчевића прошао истим путем кроз Европу с краја XVIII века од Беча до Москве и натраг, био је исто тако отмена и привлачна појава. Његови портрети о томе довољно говоре, чак ако то не бисмо знали са друге стране. Млад и леп он је лудовао о „фашанкама" и само у једној седмици од суботе до петка био је шест пута на балу идући по леду између Пеште и Будима. Лепо се носио, богат и пуст, лепо сликао и свирао у флауту, а на маскарадама дивили су се његовим белопутим прсима и његовој вештини коју је показивао пробијајући дебела храстова врата стрелом. Био је светски човек вичан лакој конверзацији на неколико језика, жене су га облетале по салонима за вист, а када се хтео женити, то је било као да је неки митрополит пошао у визитацију. Посебно је био спретан у ономе што се сматрало врлинама „француских танцмајстера" и свет се по салама где се играло у Будиму и Пешти скупљао да види како ће Текелија повести „минует”.

Правник као Текелија и Лазаревићев Јанко, Игњатовићев Шамика Кирић испољиће сличне особине. Биће свуда радо гледан гост од пургерских забава до нобл балова по Кошицама, у Венецији, у Сентандреји. Сјајно ће певати, свирати у гитару и флауту, залазити у најбоља друштва, одлично говорити неколико језика. Галантни младић лепа стаса, богат, понашања без замерке, арбитар моде коју он не само да прописује другим младићима, него је инспирише и код дама, одржавајући живу везу са Пештом и Венецијом, удешен увек као из кутије, ненадмашан играч и омиљен забављач и он је о „фашангама” стварао чуда. По маскенбаловима и по кућама где је одлазио у визите тражећи невесту, он се увек осећао у свом елементу, а на располагању је имао орман чизама и за сваки дан у седмици други фрак. Део његове раскошне тоалете, и његовог понашања које је у литератури упоређено са циришким рококом, биле су кутијице за драгоцености, испуњене израђевинама од косе: везовима и прстењем исплетеним од увојака његових обожаватељки и несуђеница.

Исти такав један полуизвезен монограм наћи ће једном приликом и Лазаревићев јунак у столу своје „Швабице”. Леп, привлачан, елегантан, тајанствен због своје повучености, Лазаревићев Јанко откриће своје га- 
лантне наклоности у дуелу, а Миша из Швабице своје познавање музике наводећи поименице низ дела ондашњег оперског репертоара. Тај Лазаревићев херој, сам себе описује као галантног господина. „Пратим је на клавиру кад пева; додајем јој игле, кад испадну; огрћем јој кабаницу, кад пође у шетњу, итд." Јанкове љубави селе се од Лабе до Београда и прате га у успоменама као Шамику Кирића.

Најзад, ту је јунак Црњанског. Исто тако као његови претходници у овом низу, леп, привлачан младић тек дошао из рата као јунак Пишчевићевих мемоара, он је грабљен и од руке до руке додаван по пречанским местима од завичаја до Сентандреје и Арада. По свештеничким и трговачким кућама удаваче и њихове породице су га разграбљале и отимале се о њега, од Пољске и Галиције до Баната, по ратиштима и војним болницама девојке су га прихватале у своја друштва, откривале му своје тајне, певале му и свирале, отварале му споменаре и срце, гасиле свећу и љубиле га у мраку да не зна која, чешљале га и одевале, заљубљене у њега и његову болест.

И такве делије, опчињавајући женици, који узбуркају сваку средину у којој се појаве, никако нису успевали да се ожене. Ако би им се то и догодило, као што је био случај са неким од њих (Пишчевић, Текелија, Рајић) то је било успркос судбини, тако да они унапред знају да ће то бити несрећно. Они се сви од реда опиру и изналазе све могуће изговоре да избегну тај одсудни, корак. Карактеристично је већ њихово лутање пред женидбу. То су праве опходње у трагању за невестом, са потајном намером да се одгоди што више и тако осујети крајња одлука.

Пишчевић отворено каже да му је у часу када се пред њим поставило питање женидбе (добра партија из породице патријарха Шакабенте) „у глави мотало само нешто о добрим коњима, о новим униформама, о официрској опреми..." Када су родитељи извршили притисак на њега, Пишчевић је упркос отпору који је осећао, пристао са „стегнутим срцем” на тај корак. По диктату оца, натеран, Пишчевић се одлучује на женидбу, али са осећањем које је карактеристично и које је сам описао: „... има нешто у мени што с противи, нешто ми говори да од тога не би било никаква добра". И доиста, пошто се женидба обави, он своју невесту не води собом у пук него је оставља са својом породицом! Тако Дафина остаје све до смрти у таласима набујале реке, несрећна страница Пишчевићеве судбине, што је он предосетио сматрајући женидбу фаталним кораком: „десило се да ми је мати убрзо умрла и да није дочекала да јој се испуни жеља, а после тога и страшни догађај што је уследио: несрећна смрт моје супруге...”

Текелија чини тачно исто што и Пишчевић, истичући готово фаталистички и унапред да његов брак нема шанси. Око 1780. он је бежао од 
родитеља да га не би оженили. Касније, када се после педесете године одлучио на женидбу, он је негде пре 1815. обишао „тражећи девојку ил нашу, ил католкињу, ил луторанку", Варад, Дебрецен, Токај, Кашаву, Еперјеш, четири мађарске вармеђе, Срем, Београд (под Карађорђем), Земун, Крушедол, и остале манастире по Фрушкој гори, заљубио се у Београду у лепу српску децу коју је видео на неком ћепенку како раде, познао да је ракија најбоља у Опову, вино у Јаску, а у Раковцу салаксија, али нигде девојку спрам себе није нашао. Идући даље у просидбу и свеједнако бирајући удаваче, Текелија је обишао Розенберг, Сентиван, Леучовију, Кежмарк, долину Магура, опет Еперјеш и најзад Хајн. Девојке које је видео увек су имале неку ману: једна је била мала и ситна, друга премлада, трећа виша од њега, четврта католкиња, а пета на којој се зауставио, није имала никаквих мана, али су зато предзнаци били врло неповољни по Текелију. Излив воде и громови, несрећни случајеви који су га пратили на том путу, показивали су му да ће иако се ожени, бити несрећне руке. На то као да је ишао и сам младожења. Текелија се женио с потајном надом да се неће оженити. И свакојаке препреке стављао је себи и удавачама на пут. Пре свега, он је разгласио да се жени само ради продужења Текелијине лозе - ја се само зато женим да би деце имао - говорио је он невестама унапред и чак постављао услов за који сам каже да га ниједна честита девојка неће прихватити: претходни лекарски преглед је ли способна да рађа. И наравно да је једина, која је такав услов прихватила била најгора међу онима које су долазиле у обзир и да га је унесрећила. Што је најинтересантније, Текелија је то знао. „Ово с таким сам страхом говорио - каже он о својим условима - бојећи се да ми она не да̂ кошар, које би поштена девојка лако учинит могла, баш ако би без сваког фелера била, а камо ли ова, која је знала каква је, пак опет је пошла и мене и фамилију моју несрећну учинила...”

Уосталом, и када се венчање обавило, Текелија је прве брачне ноћи био спречен великом кишом да оде невести, друге и треће ноћи она се нешто противила, а то ни њему самоме није сметало, како бележи у мемоарима: „обаче ја се нисам грабио за њу и тако она спавала у својој, а ја у мојој постељи". У том поступку није тешко препознати поступак који смо уочили код Пишчевића - ни он није медени месец издржао са женом у истој постељи.

Научени оваквим примерима из мемоара Пишчићева и нарочито Текелије лакше ћемо схватити ко је и какав је Шамика Кирић из Игњатовићевог романа. Он, кога су попут Пишчевића и Текелије још у детињству женили, почиње своју судбину избирача дугим путовањима. Кад се из Пеште враћа као јурат, он у Сентандреји и по малим околним местима 
не налази девојку, јер свак ту држи „из свог места што је да је лоше”. Тако одлази на пут да тражи бољу прилику, али га у томе прекида мајчина смрт. Он одлаже све за годину дана, потом почињу његова путешествија за невестом из Венеције у Кошице, потом у Ђур и ту, у суседном месту налази једну добру партију, кћер неког богатог месара, католкињу, и почиње око ње облетати. Али, са задњом намером. Он одуговлачи просидбу од бала до бала, одлаже је и због месојеђа, и најзад девојку запроси. И тада долази до разговора с оцем у којем пада једна значајна реч. Отац му скреће пажњу да је девојка друге вере и да ће то бити препрека, како се касније и испоставило. На то каже Игњатовић:

\section{„Шамика се зарумени, надао се томе”.}

Ова реченица, дискутована већ у литератури, показује у ствари да је и Шамика Кирић попут Текелије и Пишчевића унапред прижељкивао да се његови планови око женидбе не остваре и бирао такве прилике које су у ствари неприлика. Када тако буде, он се отискује путем с којег нема повратка, путем вечитог младожење. Девојке које му намењују, он удаје за друге, као рођени проводаџија, а једини случај када се решава да уђе у брачну везу је са девојком за коју је јасно да је толико болесна, да ће једва који дан преживети удају и да ће то осујетити њена родбина... „И Шамика такав младић - закључује Игњатовић - опет није се никад могао оженити; не да није хтео, но баш није могао..."

Видели смо да је проблем Швабице - да тако назовемо препреке код неједноверних бракова које су у оно време биле и правне природе, постављен још у Игњатовићевом роману. Код Лазаревића то је главни алиби јунака приповетке Швабица. Он с Аном улази у такве односе да је брак на видику, и баш тада када је веза Ане и Мише готово неповратно утврђена, Миша се трза, он измишља стотину разлога неубедљивих данашњем читаоцу, неубедљивих и за оно време, да оправда раскид са својом берлинском љубављу. „Добро знаш да се ја њоме оженити не могу - пише он побратиму - Боже мој! Шта би рекли моји, шта пријатељи, шта напослетку и поглавито ти сам? Прво, није ни Српкиња, можда ни лепа, а сирота. Па њена родбина." Осећање дужности, родољубља, обавезе према породици, према мајци (зар да му мати не разуме своју сопствену снаху!), па сестре, од које јунак Лазаревићеве приповетке тражи дозволу да се ожени туђинком и не добија је, итд. Занимљиво је и важно да се лик таквог колебљивог вечитог младожење понавља у Лазаревићевом Вертеру, где се јунак устеже да оствари физички додир са изабраницом чак и када све препреке падну, када му она дође ноћу у собу, или у Ветру, где се Јанко не може да одважи на брак и лута од Каролине негде на Лаби, 
Марије, Станке и до последњег часа се колеба да пође у сусрет последњој изабраници и запроси је.

„... ја сам био задовољан што сам нежењен - каже Јанко у Ветpy. - И мада је мајка почесто навијала да јој доведем одмену, ништа ме није вукло пред олтар. Није да сам ја из принципа желео остати нежењен, него - не знам ни ја! Напротив, ја сам сасвим делио назоре моје матере: „све са светом и кад је чему време”, али сам све то ипак остављао времену и случају. Случају? - Јест! Ја „болујем од случаја”, па сам ваљда, мало и фаталиста!”

Најзад, ту је Петар Рајић Црњанског који попут Павла Исаковича из Сеоба (а он опет много дугује Пишчевићу) не успева да нађе праву невесту између многих које срета и које га салетају од Галиције до Арада, од Кракова до Закопана, Сентандреје и Срема. Он се боји да ће се открити како не уме још око жена, он чује како га називају шапатом „Фрајла”, он се препушта теткама „које беху одлучиле да га ожене и које га оженише". Но несрећно, попут Текелије, испаде брак без деце, и ми се од Петра Рајића опраштамо у сцени где он покрива голотињу своје жене да је не гледа.

Тако ови чудни и лепи јунаци један за другим остављају за собом тајанствени знак дубоко утиснут у токове српске литературе кроз три столећа. Како они и зашто живе тако дуго и упорно у ткиву једне књижевности баш такви какви су? Сами собом они не дају одговор на то питање. Међутим, они имају још заједничких црта које их везују и које можда могу дати тражено објашњење.

\section{2. Однос према мајци}

Пре свега, код свих ових галантних јунака без изузетака присутан је један веома емотиван, наглашен однос према мајци. Помало феминизирани, осећајне природе, они још у раном детињству бивају везани за мајку и то се после устаљује и траје и даље кроз живот.

Пишчевић сам каже да је своју мајку „волео више но ишта на свету”, он се њој за љубав и одлучио на женидбу, а госпођа Пишчевић је после смрти остале деце остала изузетно привржена и везана за Симеона. Она је плачем могла од њега све да изнуди и овај страшни војник из регименти Марије Терезије које су освајале Европу, сам је признао да је „његова мати могла с њим да учини што год јој је воља". Мати Симеона Пишчевића је умрла држећи сина за руку, гледајући га у очи и последње речи 
упућујући њему. Син је мислио да ће и сам за мајком у гроб, и касније је после више од тридесет година описујући у мемоарима мајчину смрт плакао тако, да није перо видео од суза. Када се после мајчине смрти отац решио да се поново ожени, Симеон није хтео ићи у просидбу како су га звали, него је у знак протеста остао код куће.

Везаност за мајку испољио је и Текелија. У уводу мемоара одељак посвећен њој неупоредиво је већи од оног посвећеног Текелијиноме оцу. Текелија се сећа да га је мати увек више волела но брата, да му је код куће „сваке сласти давала”, и истиче како се тешко осећао када је морао да се одвоји од куће и њене љубави. Отада он је кренуо на пут од тетке до тетке, од рођаке до рођаке у женском друштву непрекидно предаван од руке до руке, од газдарице до газдарице, од слушкиње до слушкиње, тражећи и не налазећи мајчину љубав. ${ }^{1}$

И Игњатовићев Шамика поделио је ову судбину. „Материно дете”, леп, коврџаве косе, која у густим свиленим бурмама пада на чело и низ врат, он у раном детињству очарава мајку и сестру које су уживале да уплићу прсте у његове коврџе и да се њима играју милујући га. Попут Пишчевићеве матере и мати Шамике Кирића се после смрти кћери сасвим прибила уз млађега сина, она опседа учитеље молећи да никада не батинају дете и младић је изишао тако чувствителан, да за најмање ако му ко шта рекне, плаче. „Док је Шамика пред њеним очима, одвуче се од црних мисли, у том магновењу радује се, канда нема терета на срцу. Како нема Шамике, њој из гроба пред очи излази Пелагија, онако обучена као кад су је закопали". Мајчина смрт била је ненадокнадив губитак за Шамику. Он касније, кад год му се помене матер заплаче, а када му отац предложи женидбу, он одговара кроз плач:

„- Како ћу се женити, кад ми матер не иде из главе? Никад не могу је заборавити, ту добру моју матер."

Тај аргумент је један од основних и код Лазаревићевих ликова у Швабици и повестима о Јанку. Познато је како важну, одсудну улогу игра лик матере у тим делима. У Швабици готово се непрекидно супротставља

1 У једном од тих тренутака раног одвајања од мајке са Текелијом се догодила једна необична ствар коју је упамтио за цео живот и саопштио у свом почетку мемоара. По једном обичају који је изгледа био распрострањен у време рококоа више но што се да претпоставити, служавке којима је дете било поверено одводиле су га у своје просторије и са њиме и пред њим изводиле оргије које су код петогодишњег детета изазвале шок. „О родитељи - узвикује Текелија у вези с тиме - чувајте вашу децу од друштва слугу наших, као од змија и шкорпија, јер ту се сваком безакоњу уче и недозрела тела и душа оскврњује се.” 
Ани лик Мишине матере. Иза његових аргумената против женидбе Швабицом увек стоји ауторитет мајке: „Ја сам Србин, ја имам стару мајку, ја имам свој задатак!”, или: „Швабица, сирота моја мати, Србија...” Његове успомене везане за Ваљево евоцирају мајку радосну и насмејану све до часа када он уводи Ану у материн дом, а тада мати у његовим мислима престаје да се осмехује. Када хоће да се одбрани од Аниног лика, Миша пише писма матери и сестри. Због тих мисли на мајку он се боји да мисли на своју везу са „Швабицом”, - „Ох, кад би знала моја мати на како се велико дело спремам, она би се молила богу да ми да снаге!” Лик Јанкове матере у Ветру продужује и овај правац и тему даље, одсудно развија.

Јанку, који је већ зрео човек и увелико тече каријеру, добро је што живи сам са матером. Када у болници сагледа сву људску патњу и беду, он из једног јаука ишчита закључак: њима је страшно - јер немају мајке и материнске нежности. Увече он још увек као у детињству препушта да пред спавање мати угаси свећу у заједничкој соби, она га изјутра буди као дете чешкајући га по коси, и Јанко тим поводом каже: „Кака је била мама! Како блага, лепа, тиха, озбиљна, свечана!...” Када се заљуби, Јанко је потресен не толико новом љубављу, колико породичном ситуацијом, која се компликује: „Потреса ме онај грандиозни утисак на моју добру матер”. Укратко - он закључује - „бојао сам се да мама не опази на мени каку промену..." У часу када треба да донесе одлуку, на растанку са својом несуђеном вереницом, Јанко у забуни стеже руку и мајци, иако она никуда не одлази и мада се с њом не растаје. Иако га мати наговара да се ожени, он осећа да она то у суштини не жели и да никад неће прегорети. Кад год се поведе разговор о његовој женидби он осећа у мајчином гласу тон којим говори још само кад је реч о њеном, мајчином укопу и посмртној спреми. Када на крају приповетке Ветар Јанко од матере затражи дозволу да запроси девојку, он упркос њеним речима, у њеном оку чита „друкчију пресуду”. „Као Црвено море пред Мојсијем, тако се њена лепа и суха ручица испречи преда мном...” каже он. - „Таки сте ви сви данашњи младићи! - пресуђује она - Не знате шта хоћете, па не знате ни шта радите!” И тако се најзад одлазак по невесту изјаловљава и претвара у баналан изговор:

„- Идем, мамо, овде је страшан дим!”

Ни Рајић Црњанског није имун на овакву свемоћну мајчину руку. Његов повратак с фронта је у знаку материне смрти. „Пустили су ме к њој кад је издисала" - каже Рајић. А та госпођа Рајић, родом из Сентандреје, молила је на самрти сина да узме њену фотографију и да је увек држи на столу, али њену фотографију из времена пре удаје, кад јој је било 
тек осамнаест година. И потом је исте ноћи умрла и није дала да пробуде њеног јединца.

Тај лепи јединац тргао се из летаргије донете с фронта и из пољских болница само једном - када је чуо да хоће над умрлом матером да изврше страшан пагански обред пробадања срца. А потом је у очајању одлутао да обиђе место где му је мати рођена и жену коју је отац волео пре мајке, своју другу, несуђену матер.

У тим сложеним односима између синова и матера, који су очигледно остали неишчитани у делима српских писаца прохујалих векова, постоје кулминационе тачке које прелазе границу нормалног одношења деце према родитељима, постоји еротски обележен однос сина према мајци. За нашу тему овакви односи од посебног су значаја.

Има једно место у мемоарима Симеона Пишчевића и готово исто такво у Игњатовићевом роману, у којем се води разговор о томе да би, после мајчине смрти требало да се ожене и отац и син, или бар само син. У том тренутку очеви показују већу готовост да се ожене, док синови дају отпор таквоме чину не само кад су у питању очеви, него и кад је у питању њихова сопствена женидба. Код Шамике однос је тако изокренут, да се господар Софра готово згране што се Шамика понаша као да је он син, остао удовац после смрти своје матере, а не његов отац:

„- Шта ће свет рећи кад чује да се тако брзо женим? - пита Шамика оца. ли...”

- Шта може казати? И другима је мати умрла, па су се жени-

Уместо одговора Шамика одлази на пут носећи један материн прстен.

Однос Јанка према матери из Ветра Лазе Лазаревића још је експлицитнији и инцестуозно језгро ту је заклоњено само лаким тоном приповедања али су чињенице до краја наведене. Треба их само евидентирати. Јанко је зрео човек а још увек неожењен живи сам са мајком. И тај живот је сложен. Она га - то Лазаревић дословно каже - још увек мије суботом као некада док је био дете. Они, мати и син спавају у истој соби разговарајући до дубоко у ноћ или плачући у својим постељама, иако - то се писац постарао да буде очигледно - има и других слободних соба и постеља у стану. Понекад, Јанко се сећа како је некада негде у Немачкој спуштао главу у крило Каролини, својој несуђеној невести. У Београду, сада после те и других неуспелих веза, он каткад спушта главу у крило сопственој мајци и она га као некада у детињству биште и тепа му. Замена невесте и матере у оба случаја је очигледна. 
Исто ће се наћи и код Црњанског. Његов Рајић не одолева махнитој жудњи да кроз завесу крадом мотри како му матеру „голу дижу и купају”. Он осећа о даћи мирис матере - мирис мртваца свуда, „на столу, у јелу, само га у вину не беше”. А касније, када већ ожењен и наизглед утешен улази у медени месец, Рајић повлачи једну аналогију описујући своју невесту: „Она је била свуд. Мирис њеног тела, неки тежак, опојан мирис, сусретао ме је у зидовима, у вратима, у пећима, по столовима, у јелу и води, у постељи и у моме оделу, само га у вину не беше..." И ту, аналогија између матере и невесте извучена је до краја. Ово је на махове тако интензивно, да је довољно да се матер спомене, па да у „вечитом младожењи" нестане свака еротска побуда у односу на било коју другу жену. Лазаревић ће опет бити добар пример:

„Мајка и син -шта ће дакле, више?” - пита Јанко у недовршеној прози Побратими, а у Швабици се описује оваква сцена:

„Она плашљиво сеђаше мени на крилу. Неколико пута покушаваше да устане, но ја јој не дадох. Она окрете галву од мене:

- Мишо, шта радимо ми?

- Ништа рђаво, дете моје.

- Мишо, - рече она стидљиво - што би твоја мати...

Мене пресече.

- Ћути! - рекох јој.

Мора бити да сам изгледао исувише озбиљан. Она се полако диже и под некаким изговором изиђе. Ја се дигнем и одем да шетам.

- Сада ми је све јасно - рекох себи - Више је ни минута не смем лагати...”

Како се догодило да су овакви лепи, снажни и паметни људи гурнути овако дубоко у наручје мајки, остали везани за њих трајно, тако да је то ометало и омело њихов нормалан живот, брак и стварање породице?

Одговор ћемо покушати да пружимо тражећи трећи елеменат у овом троуглу - однос према оцу.

\section{3. Однос према оцу}

Писци свих наведених дела који су толико пажње посветили односу својих јунака према мајци, као да су (сем Игњатовића) хотимице прећутали очеве. А и кад би о њима говорили, проговорили би некако завијено, мирним тоном не уносећи се нимало у оцену. Па ипак, неке основне 
чињенице саопштене су. Какви су ти људи - очеви „вечитих младожења” - од капетана Стефана Пишчевића, Јована Текелије, господара Софре Кирића до очева у Лазаревићевој прози и Рајића старијег у Дневнику о Чарнојевићу? Страшан и силовит морао је бити капетан Пишчевић, официр Марије Терезије, од ког су презали не само непријатељи од Елзаса до Шлезије, него и официри аустријске армије, ако би му се замерили. Осветољубив и пуст, он је сопственим сином располагао као личном имовином - у четрнаестој години он је дечака повео у рат као добровољца, а потом га, пре но што ће сам прећи из аустријске у руску армију, послао у „извиђање”, и преселио заувек у Русију. Оженио га је тако што га је посадио и издиктовао му просидбено писмо, а сам себи довео нову жену једва шест месеци после смрти Симеонове мајке.

Исти је или сличан морао бити Јован Текелија као и Пишчевићи орођен с чувеним Рашковићима и родом из исто тако чувене војничке породице, која се прославила на балканским и руским ратиштима XVII и XVIII века. Међу оскудним интимним подацима које Текелија у мемоарима даје о оцу, истиче се да је дечак био излаган очевим казнама и да је отац био јунак на бојном пољу.

О господару Кирићу, оцу Шамикином, Игњатовић је оставио више података. Ако се из његовог приповедања (које је благонаклоно чак и према личностима и поступцима који на крају доводе до вешала) издвоје само чињенице, добиће се оваква слика. То је човек снажне воље и апсолутни господар у својој кући. Све се у тој кући морало кретати око њега и како он хоће. Ако господар Софра опази да неко не воли жуту репу - он ће баш то дати скувати; ако ко хоће да пије, онда му он кредом обележи да не може пити, а опази ли да ко неће вина, тера га на силу. Он је синовима унапред одредио животне стазе и упутио једнога на трговину (мада је Петар волео више у школу) а другога у фишкале, мада је Шамика, како се испоставило слабо учио. Он је кћерима одредио судбину матере, и са старијом се парничио, а млађу је уништио ускративши јој брак који је желела, па се тако у њој поновила судбина госпође Кирић. Јер, и њен је несуђени младожења умро када је пошла за господар Софру, при чему овај није крио да би се оженио матером удовицом да није добио ћерку. Када је у некој крчми на путу био нападнут, господар Софра је убио секиром три човека, а потом наставио да пије и пева са друштвом, као да се ништа није догодило. Када су му синови вратили мило за драго не постижући управо оно, за шта их је он спремао, он је умро жалећи себе, а не њихове упропашћене животе.

У Лазаревићевом опусу има једна приповетка која је чувена по опису оца. То је Први пут с оцем на јутрење. Отац насликан у тој исповедној 
прози супротстављен је матери. Представљен је из угла гледања деветогодишњег дечака. Био је то човек нарави чудновате; осорљив, особа која се никада не смеје и не плаче ни о смртним случајевима. Умео је отпустити млађе ни за шта, или за игру крајцарица, а сам је на коцки проћердао коња, ливаду, кућу, и сву готовину. Дечак се сећао његове тешке руке и прижељкивао да постане мека, као од кабасте хартије и да не може више њом ударити. Тиранин у кући и према матери, отац је претио да ће је оставити ако му буде пребацивала због коцке, а укућани никаква знака нежности од њега нису никад дочекали. Ишао је у кавану свако вече, дете је стрепело од његових очију и казне и често не знајући зашто га кажњавају, цептело као прут. „Чудно је живео с мојом мајком - каже Лазаревићев приповедач - увек хладан, осорљив, гори од туђина, па то ти je. А она, сирота, добра, брате, као светац, па пиљи у њега као ноје у јаје. Кад се он што обрецне, а она да свисне од плача, па још мора да крије сузе и од нас и од њега...”

Улога оца у повестима о Јанку од посебног је значаја. Када Лазаревићев Јанко у Ветру буде доведен до руба на којем се треба определити за или против невесте, мати потрже најјачи аргумент, који не може оманути, изазива у сину љубомору и сећање на оца - на оног истог који је из пиштоља пуцао на невина човека. Она иронично каже повлачећи паралелу између оца и сина у корист првога:

„Хај, хај, како су ваши стари бегенисавали девојке, а како се ви данас - заљубљујете! Сви ви, сви...!"

Код Црњанскога у Дневнику један одељак сав посвећен очевима, као да закључује ову дугу необичну поворку:

„Жао ми је ових глупих, прљавих оцева, ових који не падају на трбух пред Саломом, ових који не читају романе, ових који не знају шта је то Вилзон, ових што говоре о кравама својим подмукло. Жао ми је ових оцева. По прљавим гудурама, по смрдљивим локвама мокрим, ја их гледам како леже жути и пусти као земља. Да ме није стид, би их тешио... Јесу ли свуд тако ћутљиви оцеви? Ни један се још није вратио од куће ведар и ублажен. Сви долазе разјарени и говоре о убиству...” „Они убиством одговарају на све!”

Тако неколико поколења ратника или силовитих пустахија, смењују поколења меких, галантних лепотана, неспособних да продуже врсту, загледаних у своје матере и у своје страшне очеве, са којих капље крв. Слика је потпуна и може се, најзад, дати и њена дефиниција. 
Модерној дубинској психологији овакви односи и овакве реакције добро су познати. Сексуални живот детета у два маха доживљава врхунце - први пут према Фројду до пете године живота, према новијим психоаналитичарима у трећој години. Други пут, у пубертету. Оно што се и како се одиграва у тим раним годинама на плану сексуалности оставља печат на читав каснији живот индивидуе. Између првог и другог чина овог сазревања према Фројду долази до затишја. Од тога како ће се после затишја у пубертету наставити започето сексуално формирање, зависе човекове будуће неурозе.

Прва етапа развијања сексуалности тако добија велики значај. Тада се формирају односи према најближим - према оцу и према мајци. „Дете узима за предмете својих сексуалних жеља редовно оне који су му најближи - каже Фројд - дакле, оца и мајку, потом сестре и браћу. За дечака мати је први предмет љубави... Други родитељ се доживљава као супарник који смета и постаје често предмет правог непријатељства...” (С. Фројд, Основни појмови психоанализе). У том тренутку, под утицајем жеље да се мајка сва поседује, а та жеља зависи - како пише један модерни психоаналитичар - „не само од урођене маштовитости, темперамента и интелигенције детета, већ свакако још у знатнијој мери и од очевог става према испољавању оваквих жеља, јавља се у детету страх од казне услед слутње да оно нема права на ове жеље, односно на њихово испуњење. Уколико су сада жеље интензивније, утолико је и страх јачи. Довољна је поновљена непажња или грубост оца, при пасивном, или чак претерано заштитничком ставу мајке према мушком детету, па да овај страх остане трајно присутан, узимајући на себе врло различите форме испољавања..." (др В. Јеротић). Тај страх се испољава на неколико начина, које је Фројд препознао у античким митовима и обележио њиховим именима. То је на пример, страх дечака да га отац не прождере (мит о Кроносу) или да га отац не кастрира. Очигледно је да су они страшни ратници, свемоћни пустахије и силници, који нису презали да посеку, да се освете, да потегну пиштољ на невина човека, батину или секиру, који су судили и кажњавали у својој породици немилице као што је случај са очевима јунака овде описаних књижевних дела, изазвали у својој деци, код дечака понајпре, осећање страха, и потиснуте љубоморе, а њу су опет матере скривале тешећи и штитећи свој пород. Шамикина мати изричито каже мужу да неће допустити да јој и Шамика прође као Петар. У таквом положају сви будући „вечити младожење” нашли су се у класичном 
положају који је Фројд препознао у античком миту о Едипу, ономе што је убио и оженио се матером.

Тај однос дечака према мајци која изазива жудњу и оцу који изазива страх и љубомору, назван је у сада већ опште познатом Фројдовом опусу Едиповим комплексом.

После прве фазе секаулног развитка, у затишју које смо поменули „формирају се - каже Фројд - реакције дечијег ја, које - као стид, одвратност, моралност - бивају предодређене да однесу превагу над будућим бурама пубертета и да ограде сексуални нагон који се буди...” Како Едипов комплекс „треба да у нормалним приликама буде напуштен на крају прве фазе сексуалности код детета, како би требало да он буде од темеља до врха срушен и трансформисан, резултати те промене се сматрају пресудним за каснији психички живот човека. Али, најчешће, ствари се не догоде до краја тако и пубертет тада обнавља стари комплекс, што може имати озбиљне последице”. Укратко, уколико се и у пубертерту обнови недовољно у међувремену потиснути Едипов комплекс, долази у неким случајевима до реакције која нас враћа на нашу тему: пошто се морао одрећи мајке, дечак је решен да се одрекне и свих осталих жена.

Тако смо дошли до дефиниције „вечитог младожење” која је применљива у већој или мањој мери на све случајеве које смо описали: наши јунаци су особе које нису успеле у себи да потисну на време Едипов комплекс. И њихове судбине тиме су унапред условљене.

Milorad Pavić

THEME OF „CONFIRMED BACHELOR” IN SERBIAN LITERATURE

Summary

The theme of a „confirmed bachelor” which has so far been analysed within the studies on the work of Jakov Ignjatović (1822-1889), a prolitic Serbian novelist, is included into a wider context in this paper. The author has found the type of the subject of a "confirmed bachelor" in the following pieces of the Serbian literature of 18th to 20th century period:

1. Simeon Piščević, Memoari (about 1784),

2. Sava Tekelija, Opisanije života (prior to 1833),

3. Jakov Ignjatović, Večiti mladoženja (1878),

4. Laza Lazarević, Švabica and Povesti o Janku (after 1878),

5. Miloš Crnjanski, Dnevnik o Čarnojeviću (1920). 
The first part of the study deals with the portraying of a „confirmed bachelor" based on the comparison between all the above mentioned works; then, the second part of the paper highlights the relationship between all the mentioned characters and their mothers, whereas the third part treats the charaxters' relationship to their fathers which is of a special kind. Consequently, the conclusion leads to the definition of the type of a "confirmed bachelor" in accordance with the Freud's thesis about the Oedipus complex. All the characters have a stressed intimate relationship to their mothers which is occasionally of an incestuous character, while their relationship to their fathers is characterized by their fear, defiance, jealousy, and rivalry. The characters of the above mntioned works are the persons who did not manage to curb their Oedipus complexes on time and their destinies had been conditioned by that fact in advance.

Under the surface of narration which shows equal affections towards both the positive and the negative characters, the hidden data undoubtedly speak of the true nature of those characters. The reader, often misled by the narration, is left to a naive reading and understanding of the true messages of the relevant piece of art which remain hidden under the deeper layers of the text. 